\title{
Dossier Editorial - Training in Animation Theater: The good winds of Targoviste, Romania
} \author{
Editorial del Dossier - \\ Formación en Teatro de Animación: \\ Los buenos vientos de Targoviste, Rumania
}

Tito Lorefice ${ }^{1}$ 


\section{Abstract}

This text presents the Union International de la Marionette - UNIMA, an organization founded in 1929 in Prague, (Czechoslovakia). It presents the first International Meeting on Training in the Arts of the Puppetry held in Charleville-Mézières, France, in September 2015. And make the editorial pf the Dossier Formation to the Animation Theater that publishes exhibitions that took place at the second International Training Meeting in the Arts of the Puppet, that took place in Targoviste, Rumania, in June of 2017.

Keywords: UNIMA; Animation Theater; Marionette

\section{Resumen}

Este texto presenta la Unión Internacional de la Marionnette - UNIMA, una organización fundada en 1929 en Praga, (Checoslovaquia). Presenta el primer Encuentro Internacional de Entrenamiento en las Artes del Títeres realizado en Charleville-Mézières, Francia, en septiembre de 2015. E hace el Editorial de lo Dossier - Formación para el Teatro de Animación con exposiciones que tuvieron lugar en el segundo Encuentro Internacional de Capacitación en Artes de la Marioneta, que tuvo lugar en Targoviste, Rumania, en junio de 2017.

Palabras-claves: UNIMA; Teatro de Animation; Marionette

ISSN: 1414.5731

E-ISSN: 2358.6958

${ }^{1}$ Presidente de la Comisión de Formación Profesional de la UNIMA. Titiritero, actor, director de escena, músico y profesor. Dirige el departamento de teatro de títeres y objetos en el Instituto Artístico Mauricio Kagel de la Universidad Nacional de San Martín (Argentina). 
Without a doubt, the theater of animated forms is one of the most complex and complete phenomena of artistic expression in the contemporary scene. The territorial limits of their specificity are becoming more permeable day by day.

While the different classic techniques of the puppetry art continue alive; the contemporary scene is in constant mutation, it is fed back and coexists traversed and transformed by new trends, new technologies, new approaches, new poetic visions.

Natural incorporation and cross other artistic languages is drawing changing aesthetic. At the center of these currents, resides what today we are calling "an actor puppeteer" or "interpreter animated forms" or "puppeteer" or "multidisciplinary interpreter" or "objetual performer" or ....

But how it is formed, how they train, a multidisciplinary artist of these features? How can them acquire tools that allow to explore, create and express themself both in the field of tradition and in that of contemporaneity?

What kind of school can provide elements that serve the professional training of these artists? What kind of pedagogy will be what a teacher can apply today to his disciples can guide without pressure, teach without submitting, encourage without imposing on the field of an art with that complexity?

Induce to undertake with daring the adventure of creation; investigating, composing, deconstructing and constructing, articulating different languages in a research that can help the artist in formation find his own and particular poetic vision of the world that responds to his personal stylistic expression, will be a fundamental task of the contemporary puppeteer master.

The Union International- de la Marionette - UNIMA, an organization founded almost 90 years ago, currently brings together puppeteers from some 120 countries. The website of our Association offers some important information to learn a little about our history:

The history of UNIMA begins in Prague (Czechoslovakia) on May 20, 1929 on the occasion of the 5th Congress of Czech Marionettes, event where personalities from Bulgaria, France, Yugoslavia, Germany, Austria, Romania and the Soviet Union were invited.

In a friendly atmosphere, at the proposal of the French journalist and author, Paul Jeanne, the International Union of Puppeteers - or UNIMA was created. Establishing its headquarters in Prague, it is the first international theater association in the world. UNIMA went from being a small group of friends to becoming a global organization. The first members of UNIMA come from the puppetry world, but UNIMA is not limited to this profession; in fact, half of its founders come from other professions. The fundamental principle of UNIMA was: the rejection of corporatism.

Unfortunately, the members could not maintain the frequency of their meetings for a long time. After Prague, there was a meeting in Paris, in 1929, then another in Liege in 1930. The last one before the outbreak of World War II in 1939, was held in Ljubljana in 1933.

Nevertheless, the war did not manage to break the established relations between the puppeteers, even if their meetings had to be organized in secret, sometimes resorting to the most unsuspected media. The meetings were necessary to keep those contacts alive. This "test of fire" served as a demonstration of the power of solidarity that characterized the beginning of the history of UNIMA.

${ }^{2}$ https://www.unima.org/es/unima/historia/ 
The puppet is found in all genres of contemporary performing arts. In the theater, cinema, celebrations, performances, rituals, installations of visual arts, education, etc. Like all art, is a way of rapprochement between the population and combating intolerance and violence.

The Professional Training Commission, created in 1972, has as one of its main objectives to stimulate the exchange; among the pedagogues of different schools, among students of different cultures; continue the international reflection on teaching-learning and the training of puppeteers; encouraging also the meetings between international festivals and places of formation.

Each year, scholarships are offered for students from different backgrounds to attend courses or internships offered by some of the Schools / Programs / Puppet Training Institutes. This offer is also valid for those young people who do not receive formal training in those countries where there are no schools.

The Commission is also working to expand its internationalization with the inclusion of representatives and collaborators from Latin America, Asia, Africa and Oceania , and has proposed, among other actions, to carry out an international reflection on the pedagogy, learning and training of artists, from the exchange of ideas, methods, curricula, and mainly from the meeting of experts on the subject, to open the debate ahead constantly updated in the vast field of vocational training of puppeteers.

The first International Meeting on Puppetry Arts Training was held in Charleville-Mézières in September 2015. It brought together experts in theater education in puppets, puppeteers, artists and researchers from 25 countries.

The main objective of that meeting was to reflect on the aesthetic changes in the theater of animated forms and the situation of contemporary formation in puppet theater: the meaning of the terms used, the philosophies of formation and pedagogical practices. The program was composed in that occasion of presentations, debates and video projections that showed the practical exercise of some schools.

The second International Encounter of Formation in the Arts of the Puppet, took place in Targoviste, Romania, in June of 2017, and deepened in the reflections on the poetic transformations that the puppet theater has experienced since the 1970s: the evolution of the state of the puppet and the puppeteer, the conceptual and poetic evolution of the new forms of puppet theater and the diversity of processes and forms of teaching.

The 2017 International Meeting also aimed to discuss various topics such as: the relationship between art and society; the conceptual differences regarding institutional and alternative training places; different examples of training in professional companies; dialogues between tradition and innovation in professional training; interdisciplinary approaches in staging and its relationship with pedagogy; various systems and methods of training according to the needs of the students; the evolution of the status of the puppet in the 21st century, the complexity of the animated figures as mimesis, etc.

\footnotetext{
${ }^{3}$ Today, the Commission is composed of: President: Tito Lorefice (Argentina); Members: Irina Niculescu (USA); Lucile Bodson (France); Marthe Adam (Canadá); Greta Bruggeman (France-Belgium); Marek Waszkiel (Poland); Eloi Recoing (France); Nini Valmor Beltrame (Brazil); Svein Gundersen (Norway); Kata Csató (Hungary); Xiaoxin Wang (China), Lise Messika (Israel); Hamidreza Ardalan (Iran), Paulo Balardim (Brazil), Anurupa Roy (India). Contributors: Veronika Door (Hungary-France), Sarah Kriegler (Australia).
} 
The Urdimento Magazine, publication of the Post-Graduation Program (Masters and Doctorate in Theater) of the State University of Santa Catarina - UDESC, gives us a dimension of the quality of the discussions of our Targoviste Meeting. Here are the texts of Irina Niculescu, University of Connecticut (United States); Anca Doina Ciabotaru, George Enescu National University of Arts, (Romania); Adriana Schneider, Federal University of Rio de Janeiro (Brazil); Cariad Astles, University of London (United Kingdom); Cristina Grazioli, University of Padova (Italy); Didier Plassard, University of Montpellier (France); Fabrizio Montecchi, Gioco Vita Theater (Itália); Greta Bruggeman, Cia. Atelier Arketal (France); Izabela Brochado, National University of Brasília (Brazil); Mario Piragibe, Federal University of Uberlândia (Brazil); Miguel Vellinho, Federal University of the State of Rio de Janeiro (Brazil), ); Paulo Barladim, State University of Santa Catarina (Brazil), Phlilippe Choullet, University of Strasbourg (France).

The good winds of Targoviste continue blowing and this time they arrive in Florianópolis (Brazil), and in addition to the current edition of the Revista Urdimento, in May 2019, the city will host our 3rd Encuentro, having as a central theme of the discussions: The staging and diversity in the processes of contemporary theatrical creation, dealing broadly with the imbricated animation in contemporary theatrical procedures. The event will feature a program that will involve artists, researchers, students and professors from various countries in conferences, debates, practical classes, demonstrations of creative processes and exhibition of ongoing research banners. We have the best expectations about what we will live in Florianópolis next year.

Therefore, the reflections and questions presented here by the authors of different regions and realities force us to continue exploring, researching and exchanging ideas about the professional training of artists of an art that does not stop its evolution; on the contrary, it investigates and questions deeply in the roots of the human being, becoming also a reservoir of his imagination.

This text is also published in Spanish in this issue.

Received: $13 / 07 / 2018$

Approved: $13 / 07 / 2018$ 